\title{
INNOVATIVE LOW-RISE HOUSING CONSTRUCTION IN RUSSIA
}

\author{
Alevtina Mikhaelovna Krygina* \\ Southwest State University, Kursk, Russia \\ Natalia Mikhaelovna Krygina \\ Southwest State University, Kursk, Russia \\ Iuliia Yurevna Aksenteva \\ Southwest State University, Kursk, Russia
}

The problem of providing population with affordable and qualitative housing is up-to-datefor Russia. Indicators of housing per person in the Russian Federation are two times lower than European and three times lower than North American. An important problem is high cost of housing services and maintenance. That is whyin modern crisis economic conditions housing inaccessible for some people: for people with low income, pensioners, etc. It forces to look for new campaigns for housing construction. The basic principle of modern housing is to provide rather low construction cost, minimum maintenance expendituresand high ecological rates at all stages of residential real estate life cycle. It can be achieved, first of all, by using energy efficient technologies, building structures and materials with high operational and ecological characteristics. Innovative development concept of low-rise housing construction on the basis of energy saving and ecological approaches is offered. The concept of ecosystem approach realization at all stages of real estate life cycle is developed.

Key words: Energy efficiency, Innovative eco-real estate, Green building

\section{INTRODUCTION}

Business activity in housing and its organizational and economic perfection is one of criteria for investment evaluation and region innovative attractiveness. Global sense (meso-level) of residential real property market is to provide all categories of population with affordable and comfortable housing.

Investment and construction complex has huge potential and can be one of world and state economy "growth points" thanks to related industriesinvolvement and innovations. First of all, it can be done in the field of energy saving, environmental friendliness and resource effectiveness.

Society social and economic problems connected with negative impact minimization of anthropogenous and technogenic environment on biosphere against its assimilatory potential exhaustion are interesting for researchers throughout long period (Meadows, 1974; Cole, 1974; Peccei, 1977). Eco-economic problems have global sense. This is one of the reasons for "green" economy formation. Itsgoal is in people welfare improvementat considerable reduction of environmental risks and ecological deficiencies. The idea of ecocities and ecovillages is successfully implemented for last decades in European and Asian countries (Amanjeet. 2010; Paul, 2009; Lockwood, 2006). Ecological construction concept is connected with introduction of process innovations.

The main goal of this paper is to describe development concept of home residential real estate market on the basis of innovative organizational and economic approaches and "green" construction principles. Literature analysis shows basis of described research study. This literature study is necessary for methodological and research part of the article. Research questions are the following:

RQ 1: What are the main directions and key principles of real estate ecological efficiency realization?

RQ 2: What are the main mechanisms of ecosystem approach realization at life cycle stages 
of residential property in eco-housing reproduction at territorial and regional level for providing citizens with affordable and comfortable housing?

\section{PROBLEMS OF HOUSING CONSTRUCTION IN RUSSIA}

According to 2015 living spacesin the Russian Federation was 83,8 million sq.m. It is very far from living spaces planned at state level. 100 million sq.m a year is according to state plan. It is necessary for a solution of affordable housing problem in Russia. At the same time there is a decrease tendency in comparison with 2014 (99,5\% or 84,2 million sq.m of housing).

Indicators of housing per capita in Russia are two times lower than Central European indicators and three times lower than North American (Thompson, 1997: Golove, 1997).

Among the major factors constraining development of modern Russian investment and construction complex it is necessary to note prevailing orientation to outdated energy-intensive materials, technologies and designs. High wear of enterprisefixed assets which are the part of investment and construction complex (51,2\% to the end of 2015), technical and technological backwardness should be noted. Russian economy is two times lower than European inenergy efficiency. This factor also significantly increases living spacecost.

In modern housing constructionexpenses at a construction stage are no more than $20 \%$ of cumulative specified building costs (Krygina, 2014). The remained $80 \%$ are operational expenses. In spite of the fact that Russia is one of key energy resources consumer in the world market, in homeenergy resourcemarket the cost for consumers (first of all, in housing-and-municipal complex) is rather high. Expenses of an average Russian family on housing-and-municipal payment are about $12 \%$, and for families with low income are up to $33 \%$.

It is obvious that further development of Russian investment and construction complex is connected, first of all, with innovative power resources, resource-saving and ecological approaches, technologies, structures and materials.

According to European Commission about 40\% of general energy consumption in Europe is for various buildings. That is why one of key criteria in European market for all types of real property is energy saving. For example, German legislation doesn't allow building houses without warming. In Austria heat consumption shouldn't exceed $66,5 \mathrm{~kW} / \mathrm{h}$ in a year on sq.m (for old buildings $225 \mathrm{~kW} / \mathrm{h}$ in a year on sq. $\mathrm{m}$ is allowed). Such requirements are necessary to get permission for new cottage construction. For comparison, in Russia energy consumption in houses is 400-600 kW/h in a year on sq.m (Clinch, 2000; Landwehr, 1997).

\section{MAIN PRINCIPLES OF ECOCONSTRUCTION}

Modern global ecological problems are connected with:

- anthropogenous processes implementation without nature opportunities to compensate negative impacts of human activity;

- orientation to social and economic priorities prevalence of people's environment (Faber, 1993).

These problems were the main motivator of new social and economic development model. The priority direction in economy modernization (in spite of ensuring technological progress and competitiveness) is to improve present living conditions right now and provide favorable conditions for future generations. The solution of this task is connected with economy greening on the basis of innovative resource and energy saving, ecologically safe technologies and productions. It is important not only for economy but also for construction and housing-and-municipal services because they are forming inhabitable environment.

After analysis of expected housing construction development it is possible to have a conclusion that the only condition of housing construction development and state programs implementation for providing citizens with affordable and comfortable housing is innovative resource and energy saving, ecologically safe approaches at all real property life cycle stages (including operational stage which is about $80 \%$ of cumulative expenses (Krygina, 2014)).

At the same time, the problem of increase in effective energy and cumulative natural resources use at all stages of production cycle - production, transportation, generation and energy resources consumption - is one of priority tasks, both for economy in generaland for construction branch consuming a considerable part of fuel and energy resources. 
That is why a new segment appears in Russian real estate property market. It is called eco-housing. Ecohouses are buildings of new type which are characterized by energy efficiency and environmental friendliness and have to meet the following requirements:

- renewable resource rational use (the earth, water, wind, etc.);

- negative impact minimization by eco-real property on the environment during construction and operation;

- safe utilization of building;

- providing comfortable conditions for people accommodation.

\section{ECOLOGICAL EFFICIENCY CONCEPT OF REAL PROPERTY}

"Green" construction is effective in realization of sustainable economy development today. Taking into account considerable social load of Russian economy "green" construction can become one of innovative mechanisms for problem solution in social and economic sector today.

However today in real property home market eco trend quite often has specific realization. Sometimes it is only marketing mix for potential customers canvassing. In some cases property developer associates eco-housing only with an object situated in natural zoneor with separate innovative solution (specifically oriented). "Pragmatic" approaches connect "green" construction only with energy efficiency or resource saving, water saving, project ecological parameters and etc. (Graboviy, 2015). Each factor is essentially important in eco-construction. However distinctive feature of "green" housing is complex accounting and realization of all above-mentioned principles (Figure 1) at all life cycle stages of real property (Figure 2).

It is possible to say that now in Russia there are only separate examples of ecosystem approach realization inhousing construction. In other cases ecoprojects have fragmentary character.

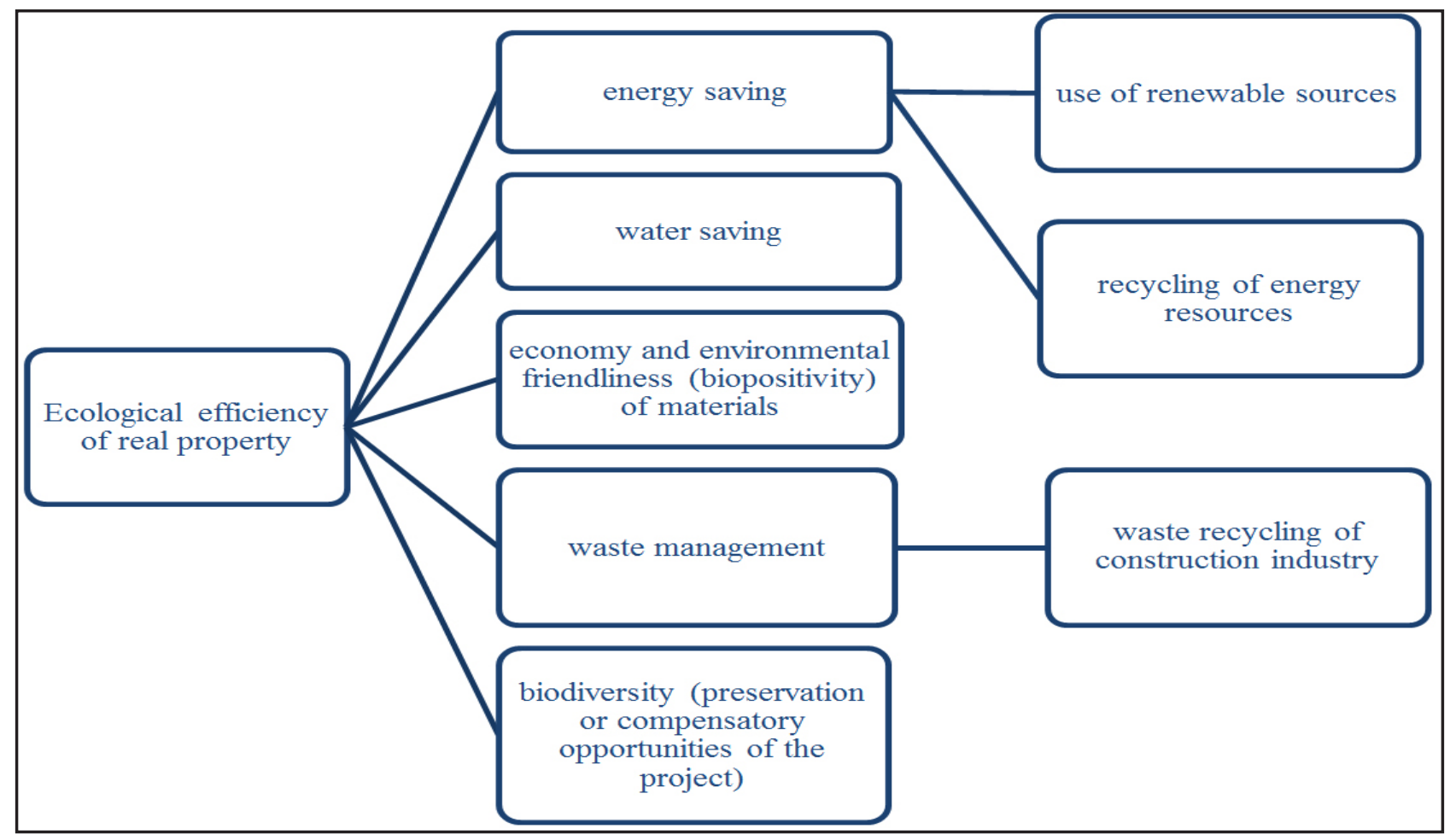

Figure 1: Ecological efficiency realization of real estate

Fundamental principle of sustainable territorial (regional) development is a balanced concept of social-and-ecological and social-and-economic system development. This development is possible in conditions of negative impact strengthening on the environment and increase of en- vironmental problems (Krygina, 2014). Complex balances are the basis for this concept implementation: requirements balance and opportunities of investment and construction complexstructural component balance (property developer, contract organizations), opportunities balance of 


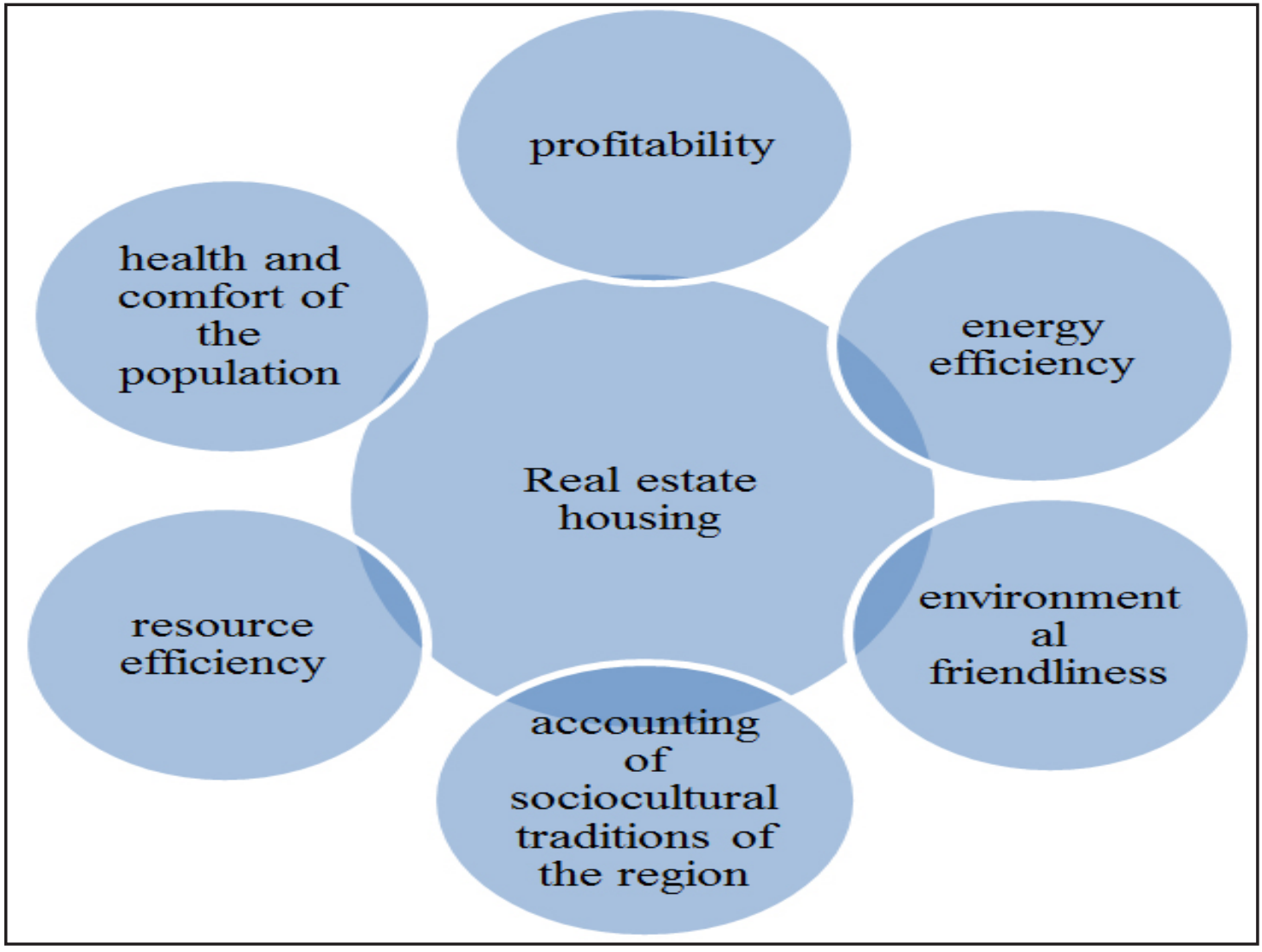

Figure 2: Main principles of residential property development

construction industry enterprises and reproduction environment capacity.

\section{METHODOLOGY}

The conceptual idea of innovative sustainable development of housing construction at regional level is essentially new approach. This approach is based on rationalization principles of human activity developmentin a region. Ensuring comfort for people accommodation at the shortest time is also important. These are basic mechanisms of expanded housing reproduction.

Development of new organizational and economic concept of eco-construction assumes the following tasks solution:

- negative impact reduction of construction activity on population and biosphere throughout real property life cycle stages;

- creation of affordable and comfortable housing market for citizens of the Russian Federation with different income;

- increase in organizational and economic construction system productivity, new job creation and involvement of skilled workers into construction industry;
- achievement of capital investment efficiency in sustainable development of eco-housing and decrease in subsequent operational expenses;

- decrease in regional energy consumption and increase in economic stability of regional power supply system, etc.

These tasks solution is directly connected with increase in territorial investment and construction complex effectiveness (TICCE).

We formulate general model of organizational and economic system effectiveness with the use of hierarchies' analysis method (Saati's method). This method allowsconsidering indicators complex on project implementation (OES productivity of territorial investment and construction complex (TICC) $\left(x_{2}\right)$, organizational and economic reliability of line construction $\left(x_{3}\right)$, investment efficiency $\left(x_{4}\right)$, efficiency of region resource capacity use $\left.\left(x_{1}\right)\right)$ :

$$
U_{\text {результ. }}^{\text {факт }}(t)=f\left(x_{1}, x_{2}, x_{3}, x_{4}\right)
$$

Conceptual economic-mathematical model of productive housing construction development at territorial and regional level can be presented 
conditional probabilistic and functional dependence of strategic task solution. This task solution is made by regional governing bodies of economical-organizational system productivity growth, organizational and economic reliability of line eco-construction and investments efficiency in eco-projects:

$$
U_{\text {pesyzlom. }}^{\text {paxm }}(t)=U_{\omega, i, j=1}^{N}\left\{H_{i}\right\},\left\{R_{z}\right\}_{\omega}, X_{\omega i} V_{j}\left\{R_{i j}^{H}\right\}, E_{j} P_{j} Q(\tau)
$$

where $X \omega i$ is expanded reproduction full cycle of territorial investment and construction complex taking into account region economic capacity;

$V_{j}$ alternative option combination defining the choice of realization optimum duration taking into account capital investments efficiency.

\section{RESULTS}

Introduction of ecosystem approach at largescale housing construction (ecovillages, ecoparks, etc.) is more effective and indicative. It predetermines a number of essential features. First of all, it is long period of eco-construction on big sites, various types of buildings, contracting organization use, investors, labor, investment, material and other resources. It is necessary to have turns during large scale construction. Designers and builders are faced with a problem of stage-by-stage engineering, transport, social infrastructure development to prevent inconvenience. Thus, there is obvious need in development of essentially new organizational and economic eco-construction mechanisms on design stages and their implementation in construction.

On a conceptual stage of project and design it is necessary to think not only about operational characteristics, but also to develop measures of increase in economic and ecological efficiency at all real property life cycle stages. In other words it is necessary to carry out full life cycle assessment.

Complexity of ecobuildings influences investments specific. Functioning and development process of such buildings is carried out, on the one hand, in conditions regulated by government institutions (municipal governing bodies) and from the other hand is based on partner relationships. Research studies show an optimality of developer consortium type as an organizational and economic form of participant's interaction in investment and construction eco-projects implementation.
A role of "design" stage increases for eco-housing. At this stage the choice of optimal organizational, economic and technology implementation solutions is carried out. So, selection of energy efficient equipment at design stage doesn't lead to serious rise in price. At construction stage it can cause the necessity of project modification and serious economic, organizational and technological complications.

Prime cost of "green" buildings at construction stage in comparison with traditional is $5-20 \%$ higher (Bulletin, 2001). However at an operational phase implementation of ecological technologies, space-planning and engineering decision allowsreceiving energy economy consumption to $25 \%$, decrease in water consumption is $30 \%$ and etc. (Bulletin, 2001).

Development of eco-housing construction can only be in integrated reproduction of innovative and technological enterprise development, territorial investment and construction complex. This can include region land development with organizational and production capacity rational use. Management process becomes more difficult and complex. It causes the necessity to coordinate increasing number of municipal and regional government bodies. It also causes to use essentially new organizational construction forms and management approaches in investment and construction processes.

\section{CONCLUSIONS}

1) Functioning and development model of organizational and economic construction system allows creating corresponding regional mechanisms and "green" construction programs of eco-housing taking into account available cumulative potential. This allows balancing of organizational and economic system effectiveness due to investment and construction complexproductivity growth and investment efficiency.

2) The offered concept of ecosystem approach realization at all real property life cycle stages allows to carry out complex reproduction of real estate eco-housing at territorial and regional level for providing citizens with affordable and comfortable housing.

\section{REFERENCES}

1) Meadows D. L. et al. Dynamics of Growth in a Finite World. Cambridge, Mass. Whright 
Allen Press Inc., 1974.

2) Cole S. World Models. Their Progress and Applicability // Futures, vol. 6, No. 3, 1974.

3) Peccei A. The Human Quality, Pergamon Press, 1977.

4) Amanjeet Singh, Matt Syal, Sue C. Grady, Sinem Korkmaz. Effects of Green Buildings on Employee Health and Productivity // Am J Public Health. 2010. pp. 1665-1668.

5) Paul F. Downtown Ecopolis: Architecture and cities for a changing climate. Springer, New York, $2009.628 \mathrm{p}$.

6) Lockwood C. Building the Green Way // Harvard Business Publishing. 2006. pp. 129-135.

7) Krygina A.M., Graboviy P.G., Kirillova A.N. Innovative development of low-rise housing property// Publishing House of the ASV, 2014.127 p.

8) Graboviy P.G., Belyakov S.I. On the results of the annual the Ministry of Construction, Housing and Utilities of the Russian Federation town-planning competition in 2015 in the nomination "The best realized project for the territory of low-rise buildings development"// Real Estate: Economics, Management, No 1, 2015, pp. 70-77.
9) Bulletin RWAY. June 2001, N 195, pp. 108-119.

10) Faber, M. Evolution, Time, Production and Environment / M. Faber, J. Proops.- Berlin, 1993. - 203 p.

11) Landwehr M., Jochem E. From primary to final energy consumption - analyzing structural and efficiency changes on the energy supply side / Energy Policy. 1997. vol.. 25. No.7-9. pp. 693-702.

12) Golove W.H., Schipper L.J. Restraining carbon emissions: measuring energy use and efficiency in the USA / Energy Policy. 1997. vol. 25. No.7-9. pp. 803-812.

13) Thompson P.B. Evaluating energy efficiency investment: accounting for risk in the discounting process / Energy Policy. 1997. vol. 25. No 12. pp. 989-996.

14) Clinch J.P., Healy J.D. Cost-benefit analysis of domestic energy efficiency /Energy Policy. 2000. vol. 29. No.2. pp. 113-124.

Paper sent to revision: 28.07.2017.

Paper ready for publication: 11.09.2017. 